\title{
Watching Korean Dramas: Youth's BEHAVIOURAL INTENTION TOWARDS SOUTH KOREA
}

\author{
Loke Jingyi \\ Universiti Tunku Abdul Rahman, Malaysia \\ cljy26@1utar.my \\ Santhidran Sinnappan \\ Universiti Tunku Abdul Rahman, Malaysia \\ santhidran@utar.edu.my \\ Thinavan Periyayya \\ Universiti Tunku Abdul Rahman, Malaysia \\ thinavan@utar.edu.my
}

\begin{abstract}
This study was aimed to explore the influence of Korean dramas on behavioural intentions toward South Korea among youth. A total of 547 samples were collected from Malaysian youth via an online survey through social media. The results suggest that youth' behavioural intentions toward South Korea is positively influenced by the viewing, likings of Korean dramas and attitude toward South Korea. The viewing and positive feelings toward Korean dramas can yield a positive attitude toward South Korea. Furthermore, attitude toward South Korea was found out to be a partial mediator in the indirect effect of viewing and likings of Korean dramas. Implications of the study findings are discussed in this study.
\end{abstract}

Keywords: Korean drama, behavioural intentions, cultivation theory, youth, Malaysia

\section{INTRODUCTION}

Korean wave had arrived in Malaysia since the early 2000s (Aisyah, 2019). Since then, there are high demands for South Korea's cultural and commercial products in Malaysia. As Korean media can be accessed effortlessly through broadcasting stations and the internet, the young people in Malaysia are seen engaging in the Korean wave. Since then, Korean popular culture had been absorbed into Malaysian teenager's lives to a great extent (Zailin, Khalifah \& Ridhuan, 2014). Korean dramas became popular in Malaysia when the Korean wave hit Malaysia and have been aired on national television station. As the numbers of audiences engaged with Korean dramas increases, the interest in Korean culture was also expected to increase too (Ariffin, Bakar \& Yusof, 2018). As a consequence, the younger generation started to admire Korean culture, language and fashion. 
Malaysians had developed favourable views toward Korean society through the consumption of Korean dramas (Cho, 2010). Now with the advance of digital media, Malaysian audiences can easily get access to Korean media, including Korean drama, anytime and anywhere they want using their digital devices. With this, it will be easier to cause changes to Malaysians' way of thinking and living. A study done by Ainslie (2016) showed that those Thai Korean drama fans had constructed "Koreanness" and had incorporated it into their lives, leading to changes in their construction and discourses of "Thainess". Another study done on Algerian fans also showed that the Korean wave had impacted their daily discourse (Touhami \& Al-Haq, 2017). The result of such studies on Korean popular cultural influence had shown a possible concern for the Korean wave as the existing Malaysian youth culture may change.

Park had reported that the relationship between Malaysia and South Korea had been friendly and cooperative since their established diplomatic relations in 1960 (as cited in Cho, 2010). Both countries are mutually important trading partners (Cho, 2010). Naturally, Korean dramas will be imported into Malaysia. Winter Sonata and Autumn in My Heart, which were popular Korean drama during that time, were introduced to Malaysian viewers through television (Cho, 2010; Aisyah, 2019). Winter Sonata was the first Korean drama aired in Malaysia in 2002. Korean dramas have been popular in Malaysia as compared to other foreign dramas mainly due to their relatable storylines and Asian values that can connect with their viewers emotionally (Begum, 2019). Viewers will become engaged in the dramas when they recognize the similarities between them and the characters or the stories in the dramas (Ariffin, 2016).

Currently, Malaysians can watch Korean dramas through several television channels. Furthermore, Malaysians can watch Korean dramas online through various online streaming services (Begum, 2019). The popularity of Korean dramas in Malaysia can be seen when the actors or actresses visited Malaysia for events or meeting with fans. For instance, when Park Shin Hye-a well-known Korean actress - came to Malaysia to promote the launching of a Korean cosmetic brand, Mamonde, it was reported that more than 2000 fans, consisting of male and female young adults, had gathered at the event (Bibi, 2016). In 2016, AirAsia Group Limited had embraced the Korean wave by sponsoring a Korean drama, named On the Way to the Airport by Korean Broadcasting System (KBS) (AirAsia, 2016; Aisyah, 2019). The filming for the scenes in the aviation industry and Kuala Lumpur was reported to have been fully sponsored by AirAsia.

\section{LITERATURE REVIEW}

Media can influence people by changing their beliefs and have a direct influence on their behaviours through persuasion (as cited in Enikolopov \& Petrova, 2018). Televisions had shaped the way of thinking and relating of the society (West \& Turner, 2014). Previous research had found that the media can influence their viewers' attitudes and behaviours, regardless of the viewer's nationalities (Hasegawa, 2006; Jalaluddin \& Ahmad, 2011, Lita \& Cho, 2012; Ariffin, 2016; Wu \& Wang, 2017). Japanese viewers' image of Korea and Koreans had changed and improved due to Korean dramas (Hasegawa, 2006). The extreme tension relationship between Japan and Korea had also shifted with the popularity of Korean dramas in Japan (Creighton, 2009). Hence, it is not surprising that Korean dramas can influence viewers' 
lifestyles, purchasing habits, brand preferences and also enhance the country of origin's image (Cho \& Agrusa, 2007; O’Connor, Flanagan \& Gilbert, 2008; Köksal \& Gjana, 2015).

\section{Cultivation theory}

The main theory involved when discussing about television viewing effect on viewers is the cultivation theory developed by Gerbner in 1969 (as cited in Lita \& Cho, 2012). This theory was used to explain the effect of prolonged television watching on the viewers. Heavy viewers are most likely to reflect what they had seen on television compared to light viewers (Gerbner, Gross, Morgan, M., \& Signorielli, 1986). People who watch television extensively tend to believe the media contents portrayed as reality (Namdar, Hassaan, \& Naseem, 2013). Heavy viewing can also lead different groups of people to come together and share the same views on the social reality due to mainstreaming (Severin \& Tankard, 2014). This had caused heavy television viewers from different co-cultures to have similar beliefs about the world (West \& Turner, 2014). Besides influencing viewers' attitude, according to Meyer, cultivation theorists argue that viewing of television may influence consumer behaviour on purchasing goods due to the media they had watched (as cited in Kim et al., 2009).

\section{Conceptual Framework}

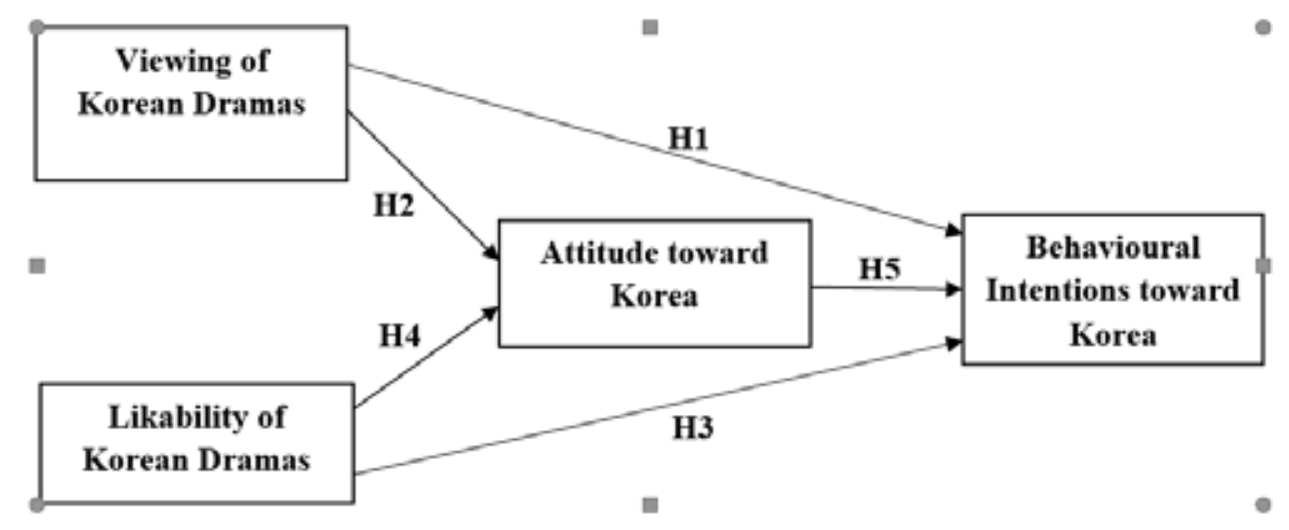

Figure 1. Conceptual model

\section{Viewing of television}

Researches have supported the idea that media, such as films, TV series and shows have the ability to influence their viewers and cause them to take on certain attitudes towards the country of origin (Su, Huang, Brodowsky, \& Kim, 2011; Lita \& Cho, 2012; Köksal \& Gjana, 2015). Dramas not only give entertainment but also channel messages and promote brands to their viewers (Huang, 2009).

\section{Likability of dramas}

Summarization of a viewing experience evaluation is known as the program likings. These feelings and likings of viewers are important as they can influence the viewers' viewing experiences (Murry, Lastovicka, \& Singh, 1992). The positive feelings of the viewers can be developed by the storylines and the characters in the dramas (Russell, Stern, \& Stern, 2006). This can lead viewer's beliefs and principles for their relationships and personal lives to be 
influenced by the viewing experience of Korean dramas (Hassim, Jayasainan \& Khalid, 2019). Wu and Wang's (2017) research had suggested that the likability of the dramas influenced the viewers' attitude toward the country of origin. Lee, Ham, and Kim's research (2015) had also suggested that the likability of dramas had a positive relation with the country of origin's image and the positive image was able to influence the consumer's preferences on restaurants. These show that the positive outcome of the likability of the dramas is similar to the outcome proposed by the cultivation effect.

\section{Attitude toward country of origin}

Korean dramas are suggested to improve Korea's image among foreign viewers (Hasegawa, 2006; Cho, 2010). The familiarization of the country of origin through watching television dramas can lead to the acceptance of the country's culture and later the development of positive attitude toward the country (Lee et al., 2015; Suh, Hur, \& Davies, 2016). With the likings of Korean dramas, viewers can also feel connected and form positive attitude toward Korea (Tsai \& Lu, 2012). This positive attitude then will produce purchase intentions for the country's products (Suh et al., 2016). Previous researches have also found out that the country's image plays a role as mediator in influencing consumer behaviours (Han, 1990; Son \& Kijboonchoo, 2016). Han's (1990) research had viewed the country's image as a "halo" in consumer choice behaviours, while Son and Kijboonchoo's (2016) had suggested the country of origin as an important mediator for the Korean wave influence on Korean products purchase intentions. By acknowledging the presence of the mediating variable, the additional variable in the indirect relationship can be judged to see whether its involvement brings about the desired effects and also to understand the impact on the behavioural change (Solimun \& Fernandes, 2017).

\section{RESEARCH QUESTION AND HYPOTHESES}

Through this study, the possible behavioural intentions towards South Korea formed by watching Korean dramas among Malaysian youths was determined. This study also determined the role of the attitude towards South Korea among Malaysian youths' viewers in the cultivation effect. This will be benefited when understanding the influence of foreign media is able to influence viewers' behaviours despite the cultural differences and language barrier. This study also gives insight into the demand and interest in South Korea and Korean culture among the Korean drama watching youths in Malaysia. Therefore the research question and hypotheses for this study is as follows:

RQ Can viewing and liking of Korean drama influence the behavioural intentions towards South Korea with attitude toward South Korea acting as mediator among Malaysian youths?

H1 There is a positive relationship between viewing of Korean dramas and behavioural intentions toward South Korea.

H2 There is a positive relationship between viewing of Korean dramas and attitude toward South Korea.

H3 There is a positive relationship between likability of Korean dramas and behavioural intentions toward South Korea. 
H4 There is a positive relationship between likability of Korean dramas and attitude toward South Korea

H5 There is a positive relationship between attitude toward Korea and behavioural intentions toward South Korea.

H6 Attitude toward Korea act as mediation factor for positive relationship between viewing of Korean dramas and behavioural intentions toward South Korea

H7 Attitude toward Korea act as mediation factor for positive relationship between likability of Korean dramas and behavioural intentions toward South Korea

\section{METHODS}

Snowball sampling was used to collect data from samples. The targeted respondents need to be Korean drama viewers and aged between 15 and 30 years old. The age range is according to the amended Youth Societies and Youth Development Act 2007 (Act 668) (Kumar \& Zainuddin, 2019; Yunus \& Landau, 2019).

Social media was used to approach Korean drama viewers in Malaysia for the data collection. The survey link was shared on Twitter and requested a few existing fan-pages on social media related to Korean drama or Korean pop music, for example, Kpop Fans to retweet the survey link to reach larger groups of respondents. The instruments used in this study were adapted from previous studies and have high reliability and validity (Carveth \& Alexander, 1985; Yoo, Jo \& Jung, 2014; Lee et al., 2015; Suh et al., 2016; Wu \& Wang, 2017). Path analysis was conducted with partial least squares structural equation model (PLS-SEM) using SmartPLS 3.

\section{Instruments}

Questionnaire was used in this study. To measure the viewing of Korean dramas, the instrument was adapted from Yoo et al.'s (2014) research. The instrument was developed by Carveth and Alexander (1985). The amount of time per day spent viewing Korean dramas and number of different Korean dramas viewed per day was collected. In addition to the instrument adapted above, a question from the viewing variables used by Carveth and Alexander (1985) was added to ask viewers on the estimation of how many years they had been watching Korean dramas. This question was added to access the possible long-term exposure effect (Carveth \& Alexander, 1985).

Likability of the Korean drama instrument was adapted from Wu and Wang's (2017) research. This instrument was developed according to Murry et al.'s (2012) research to measure the likability of Korean dramas through the viewers' liking and attitude formed from self-evaluation (as cited in Wu \& Wang, 2017). The items used in this instrument were also similar to the instrument used in Lee et al.'s research (2015) for likability of Korean dramas, where it included the elements of feelings, attractiveness and interest. The instrument consisted of 5-items. These items were "Overall, I have positive feelings toward Korean dramas", "Overall, I think that Korean dramas are attractive", "Overall, I am interested in Korean dramas", "Overall, I like to watch Korean dramas" and "Overall, regarding Korean dramas there is something that attracted me". The instrument was measured using a 5-point Likert scale, ranging from "strongly disagree" (1) to "strongly agree" (5). The Cronbach's 
alpha for the instrument was 0.890 , while the average variance extracted (AVE) value is 0.657 (Wu \& Wang, 2017).

Instrument used to measure the feeling and attitude of the respondents towards the country of origin was adapted from Suh et al.'s (2016) research. There are 3 subscales in the developed instrument. These instruments measured the attitude toward Korea, where the feelings of the viewers towards Korea as a country, Korean nationals and Korean products were recorded. There was a total of 10-items in the instrument. The subscales measured the attitude toward the country (3-items), Korea's companies (3-items) and Korea products (4-items). The 3 subscales items were such as "I want to live in Korea", "I think Korean companies are trustworthy" and "Korean products are good value for money". The Likert scale is a 5-point scale, ranging from "very low" (1) to "very high" (5). The reported Cronbach's alpha for attitude toward the country, attitude toward a company and attitude toward a product were $0.834,0.826$ and 0.766 respectively. While the AVE value for attitude toward the country, attitude toward a company and attitude toward a product are $0.695,0.589,0.520$ respectively (Suh et al., 2016).

The instrument used to measure the behavioural intentions was adapted from Yoo et al.'s study (2014). Previously this instrument was used in Carrillat et al.'s study (2005) to measure the purchase intention (as cited in Yoo et al., 2014). The instrument was then modified by Yoo et al. (2014) to measure the behavioural intentions toward Korea. The modified instrument not only recorded the intention for purchasing, but also other possible behaviour intentions that may occur reflecting the attitude toward the country of origin. There were five items in this instrument. The items included were "I would like to visit or return to Korea", "I would like to learn Korea language", "I would like to have a Korean friend", "I would like to purchase Korea's cultural products" and "I would like to purchase Korea's commercial products". The measurement used the 5-points Likert scale, ranging from "least interested" (1) to "most interested" (5). The reported internal consistency reliability of the scale was $\alpha=$ 0.78 (Yoo et al., 2014).

\section{RESULT}

Data collection was done through the help from fan-pages on Twitter to share the link to their followers in order to reach the minimum number of samples required. A total of 575 samples were collected. Screening of the data collected was done to exclude respondents who did not match with the study criteria, which are age and nationality. A total of 28 samples were excluded from this study due to age (15 to 30 years old) criteria not matched. Thus, the total number of samples used for this study was 547 samples.

The average respondents' age was 21.883 years old. There were $16(2.9 \%)$ male respondents and $531(97.1 \%)$ female respondents. $473(86.5 \%)$ respondents were Malay, 47 $(8.6 \%)$ Chinese respondents, $4(0.7 \%)$ Indian respondents and $23(4.2)$ other races such as Kadazan, Iban, Dusun, Bajau, Bidayuh, Bumiputera from Sabah and Sarawak. 334 (61\%) of the respondents were students, 164 (30\%) respondents were working adults and 49 (9\%) of them were unemployed. Out of the 547 respondents, $440(80.4 \%)$ respondents had been watching Korean dramas for more than 4 years. 
Table 1. Constructs

\begin{tabular}{|c|c|c|c|c|c|}
\hline Constructs & Items & $\begin{array}{l}\text { Factor } \\
\text { Loadings }\end{array}$ & $\begin{array}{l}\text { Cronbach's } \\
\text { alpha, } \alpha\end{array}$ & $\begin{array}{l}\text { Composite } \\
\text { Reliability }\end{array}$ & AVE \\
\hline \multirow{3}{*}{$\begin{array}{l}\text { Viewing } \\
\text { of Korean } \\
\text { Drama }\end{array}$} & & & 0.551 & 0.806 & 0.671 \\
\hline & $\begin{array}{l}\text { Number of hours spent in a day } \\
\text { on viewing Korean drama }\end{array}$ & 0.915 & & & \\
\hline & $\begin{array}{l}\text { Number of hours spent in a day } \\
\text { on viewing Korean drama }\end{array}$ & 0.721 & & & \\
\hline \multirow{6}{*}{$\begin{array}{l}\text { Likability } \\
\text { of Korean } \\
\text { Drama }\end{array}$} & & & 0.929 & 0.947 & 0.782 \\
\hline & $\begin{array}{l}\text { Positive feelings toward South } \\
\text { Korean drama }\end{array}$ & 0.826 & & & \\
\hline & Korean drama is attractive & 0.887 & & & \\
\hline & Interested in Korean drama & 0.926 & & & \\
\hline & $\begin{array}{l}\text { Like to watch South Korean } \\
\text { drama }\end{array}$ & 0.902 & & & \\
\hline & $\begin{array}{l}\text { There is something that } \\
\text { attracted me }\end{array}$ & 0.872 & & & \\
\hline \multirow{11}{*}{$\begin{array}{l}\text { Attitude } \\
\text { toward } \\
\text { South Korea }\end{array}$} & & & 0.838 & 0.871 & 0.405 \\
\hline & $\begin{array}{l}\text { Think South Koreans are } \\
\text { friendly and likeable }\end{array}$ & 0.579 & & & \\
\hline & $\begin{array}{l}\text { Think South Koreans are } \\
\text { reliable }\end{array}$ & 0.575 & & & \\
\hline & Want to live in South Korea & 0.670 & & & \\
\hline & $\begin{array}{l}\text { Think South Korean companies } \\
\text { are reputable }\end{array}$ & 0.559 & & & \\
\hline & $\begin{array}{l}\text { Think South Korean companies } \\
\text { are trustworthy }\end{array}$ & 0.548 & & & \\
\hline & $\begin{array}{l}\text { Want to work for a South } \\
\text { Korean company }\end{array}$ & 0.666 & & & \\
\hline & $\begin{array}{l}\text { Korean products are good value } \\
\text { for money }\end{array}$ & 0.635 & & & \\
\hline & $\begin{array}{l}\text { Korean products have a good } \\
\text { design }\end{array}$ & 0.669 & & & \\
\hline & Korean products are innovative & 0.724 & & & \\
\hline & $\begin{array}{l}\text { Korean products are equipped } \\
\text { with leading technology }\end{array}$ & 0.710 & & & \\
\hline
\end{tabular}


Behavioural

0.869

$0.905 \quad 0.656$

toward

South Korea

Would like to visit or return to

South Korea

0.815

Would like to learn the Korean

language

0.843

Would like to have a Korean

friend

Would like to purchase Korean

cultural products

0.804

Would like to purchase Korean

commercial products

0.762

Note: The item for 'How many years have you been watching Korean dramas' is excluded because of factor loading that was lower than 0.500 .

The factor loadings for all the instruments used in this study are recorded in Table 1. For the viewing of Korean dramas, the item regarding the estimation of years of watching Korean dramas was excluded from the construct as the factor loadings was lower than 0.500. Nevertheless, the data collected from the result was retained to understand the respondents' engagement with Korean drama time period.

To determine the internal construct validity, the value of the Cronbach's alpha for a variable should be higher than 0.700 . However, according to Bagozzi and Yi, and Hair et al., composite reliability was suggested to be used as a replacement because Cronbach' alpha gave a conservative measurement in PLS-SEM (as cited in Wong, 2013). Besides, variables with Composite Reliability reading higher than 0.60 could be accepted (Wong, 2013). Meanwhile, for the convergent validity, the Average Variance Extracted (AVE) value for the variable should be higher than 0.50 . Despite of that, AVE higher than 0.4 could also be accepted if the composite reliability was higher than 0.6 (Fornell \& Larcker, 1981). Hence, the construct for viewing of Korean dramas and attitude toward Korea were acceptable (Table 1).

Redundancy analysis was done to the determine the convergent validity for attitude toward South Korea variables. The result for both path coefficient and $\mathrm{R}^{2}$ value was 1.00. Convergent validity was established as the correlation between the variables was higher than 0.80 (Hair et al., 2017). This showed that the judgment of formative indicators was well covers through the assessed using the reflective scale.

Table 2. Discriminant validity

\begin{tabular}{lcc} 
Behavioural Intentions toward South & $\begin{array}{c}\text { Attitude towards South } \\
\text { Korea }\end{array}$ & $\begin{array}{c}\text { Behavioural Intentions } \\
\text { toward South Korea }\end{array}$ \\
Korea & 0.601 & 0.484 \\
Likability of Korean Dramas & 0.448 & 0.234 \\
Viewing of Korean Dramas & 0.183 & \\
\hline
\end{tabular}


Discriminant validity for the measurement model was accessed using the HTMT Criterion (Henseler, Ringle \& Sarstedt, 2015). The HTMT values shown in Table 2 were below 0.90. This showed that the discriminant validity was established between constructs with value below than 0.90 (Hair et al., 2017).

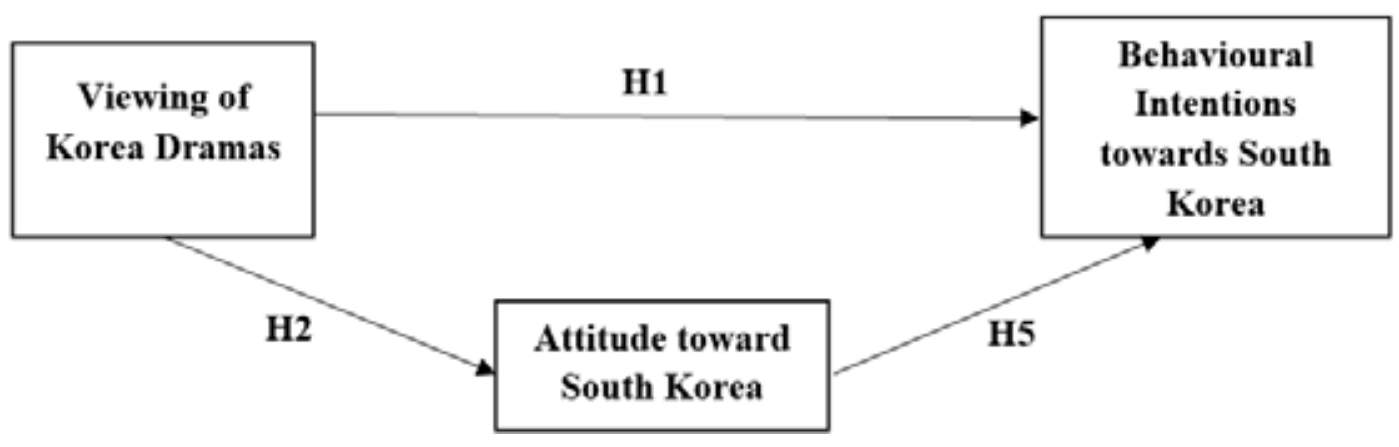

Figure 2. Conceptual model for viewing of Korean dramas

The path (Figure 2) was analysed firstly without the attitude toward Korea to determine the direct effect. The data were first run using the PLS algorithm to analyse the relationship between the viewing of Korean dramas and behavioural intentions toward South Korea.

Table 3. Path coefficient and bootstrapping result for direct effect of viewing of Korean dramas on behavioural intentions toward South Korea

\begin{tabular}{lcccccc}
\multicolumn{1}{c}{ Path } & H & $\begin{array}{c}\text { Path } \\
\text { Coefficient }\end{array}$ & STDEV & $\begin{array}{c}\text { T } \\
\text { Statistic }\end{array}$ & P Values & Result \\
$\begin{array}{l}\text { Viewing } \rightarrow \\
\text { Behavioural Intentions }\end{array}$ & H1 & 0.176 & 0.037 & 4.744 & $0.000^{*}$ & Supported \\
\hline
\end{tabular}

*Significant level at 0.05

The result showed that the direct effect had a positive relation with a 0.176 path coefficient (Table 3). After that, bootstrapping was run to determine the significance of the direct effect. Result was suggested to be significant when p-value shown less than 0.05 (Hair, Hult, Ringle, and Sarstedt, 2017). The $\mathrm{p}$-value for the direct effect was $\mathrm{p}<0.000$ showing a significant result (Table 3). Hence, H1 is supported, where the viewing of Korean dramas and behavioural intentions toward South Korea had a positive relationship.

As the result showed that the direct effect was significant, the variable, attitude toward South Korea was added into the model. This was to calculate the indirect effect in the model. PLS algorithm was done to analyse the path coefficient of the relationships. 
Table 4. Path coefficient and bootstrapping result for indirect effect of viewing of Korean dramas on behavioural intentions toward South Korea

\begin{tabular}{|c|c|c|c|c|c|c|c|}
\hline Path & $\mathrm{H}$ & $\begin{array}{c}\text { Path } \\
\text { Coefficient }\end{array}$ & CI & STDEV & $\begin{array}{c}\mathrm{T} \\
\text { Statistic }\end{array}$ & $\begin{array}{c}\mathbf{P} \\
\text { Values }\end{array}$ & Result \\
\hline $\begin{array}{l}\text { Viewing } \rightarrow \\
\text { Behavioural } \\
\text { Intentions }\end{array}$ & H1 & 0.088 & 0.262 & 0.035 & 2.598 & $0.009^{*}$ & Supported \\
\hline $\begin{array}{l}\text { Viewing } \rightarrow \\
\text { Attitude }\end{array}$ & $\mathrm{H} 2$ & 0.161 & 0.258 & 0.042 & 3.735 & $0.000^{*}$ & Supported \\
\hline $\begin{array}{l}\text { Attitude } \rightarrow \\
\text { Behavioural } \\
\text { Intentions }\end{array}$ & H5 & 0.532 & 0.506 & 0.028 & 19.201 & $0.000^{*}$ & Supported \\
\hline
\end{tabular}

*Significant level at 0.05

The path coefficient for the viewing of Korean dramas and behavioural intentions toward South Korea decreased to 0.088 after the attitude toward South Korea was added. Nevertheless, the direct effect is still showed positive relationship. The indirect effect also showed positive relations from viewing of Korean dramas to attitude toward South Korea and from attitude toward South Korea to behavioural intentions toward South Korea with a path coefficient of 0.161 and 0.532 respectively (Table 4 ).

The confidence interval (CI) of $95 \%$ was recorded in Table 4 . Bootstrapping result for the model showed a significant result with $p$-value $<0.000$ for the indirect effects. This showed that there was positive relationship between viewing of Korea dramas and attitude toward South Korea, and between attitude toward South Korea and behavioural intentions toward South Korea, supporting H2 and H5. As for the direct effect, the p-value was 0.009 supporting H1 (Table 4).

Since the p-value for both the direct and indirect effects showed significant results, H6 was supported as mediation occurred in the model. According to the mediator model (Zhao, Lynch, \& Chen, 2010; Hair et al., 2017), the attitude toward South Korea was identified as partial complimentary mediator as the direct and indirect effect showed positive and significant results. This indicated that the positive relationship between the viewing of Korean dramas and behavioural intentions toward South Korea was partially mediated by attitude toward South Korea.

Table 5. Coefficient of determination (R2) and predictive relevance (Q2) for viewing of Korean dramas model

\begin{tabular}{lcc}
\multicolumn{1}{c}{ Construct } & $\mathbf{R}^{2}$ & $\mathbf{Q}^{2}$ \\
\hline Behavioural Intentions toward South Korea & 0.307 & 0.197 \\
Attitude toward South Korea & & 0.008 \\
\hline
\end{tabular}


Table 6. Effect size (f2) for viewing of Korean dramas model

\begin{tabular}{lcc} 
Behavioural Intentions toward South & $\begin{array}{c}\text { Attitude towards South } \\
\text { Korea }\end{array}$ & $\begin{array}{c}\text { Behavioural Intentions } \\
\text { toward South Korea }\end{array}$ \\
$\begin{array}{l}\text { Korea } \\
\text { Viewing of Korean Dramas }\end{array}$ & 0.399 & 0.012 \\
\hline
\end{tabular}

Cohen (1988) has suggested that $\mathrm{R}^{2}$ value of $0.02,0.13$ and 0.26 indicated weak, moderated and substantial level of predictive accuracy respectively. Table 5 showed that viewing of Korean dramas and attitude toward South Korea have substantial level of predictive accuracy, explaining $30.7 \%\left(\mathrm{R}^{2}=0.307\right)$ of the variance of behavioral intentions toward South Korea. Meanwhile, the predictive relevance and effect size were reported in Table 5 and Table 6 respectively.

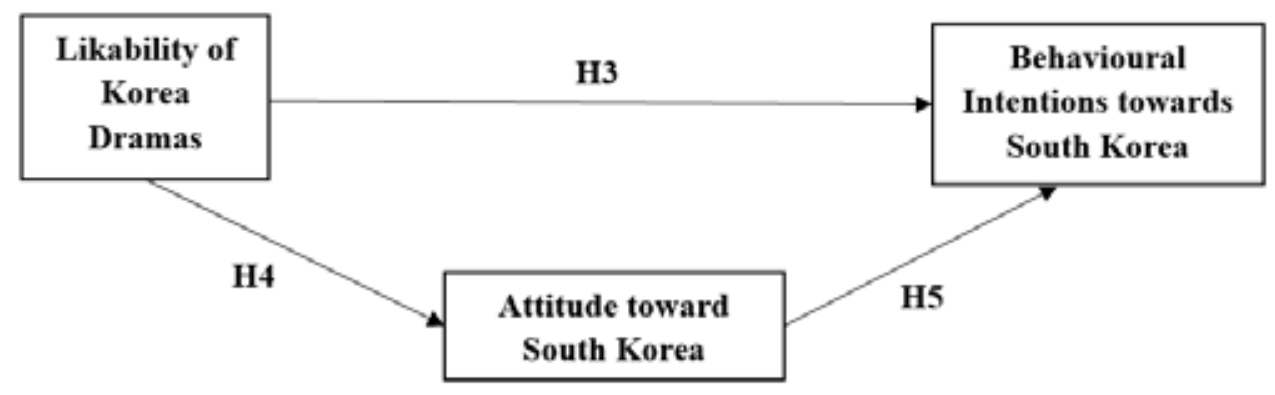

Figure 3. Conceptual model for likability of Korean dramas

The relationship between likability of Korean dramas and behavioural intentions toward South Korea was also tested. The model (Figure 3) was first analysed without the attitude toward South Korea to test the direct effect.

Table 7. Path Coefficient and Bootstrapping result for direct effect of likability of Korean dramas on behavioural intentions toward Korea

\begin{tabular}{lcccccc} 
Path & H & $\begin{array}{l}\text { Path } \\
\text { Coefficient }\end{array}$ & STDEV & T Statistic & P Values & Result \\
$\begin{array}{l}\text { Likability } \rightarrow \\
\text { Behavioural Intentions }\end{array}$ & H3 & 0.438 & 0.041 & 10.74 & $0.000^{*}$ & Supported \\
\hline
\end{tabular}

*Significant level at 0.05

The path coefficient was calculated by the PLS algorithm, where the result showed 0.438 (Table 7), indicating that the direct effect between likability of Korean dramas and behavioural intentions toward South Korea had a positive relationship.

Meanwhile, the bootstrapping result showed that the p-value for the direct effect was $\mathrm{p}<0.000$ (Table 7). The result was significant as the p-value was smaller than 0.05 (Hair et al., 
2017). Thus, H3 was supported indicating that likability of Korean dramas had a positive relation with behavioural intentions toward South Korea.

As the direct effect was significant, attitude toward South Korea was added to the model to test the indirect effect. PLS algorithm was run again to analyze the path coefficient.

Table 8. Path Coefficient and bootstrapping result for indirect effect of likability of Korean drama on behavioural intentions toward Korea

\begin{tabular}{lccccccc}
\multicolumn{1}{c}{ Path } & H & $\begin{array}{c}\text { Path } \\
\text { Coefficient }\end{array}$ & CI & STDEV & $\begin{array}{c}\text { T } \\
\text { Statistics }\end{array}$ & P Values & Result \\
$\begin{array}{l}\text { Likability } \rightarrow \\
\text { Behavioural }\end{array}$ & H3 & 0.258 & 0.409 & 0.044 & 5.871 & $0.000^{*}$ & Supported \\
$\begin{array}{l}\text { Intentions } \\
\begin{array}{l}\text { Likability } \rightarrow \\
\text { Attitude }\end{array}\end{array}$ & H4 & 0.407 & 0.522 & 0.037 & 10.919 & $0.000^{*}$ & Supported \\
$\begin{array}{l}\text { Attitude } \rightarrow \\
\text { Behavioural } \\
\text { Intentions }\end{array}$ & H5 & 0.433 & 0.406 & 0.035 & 12.313 & $0.000^{*}$ & Supported \\
\hline
\end{tabular}

*Significant level at 0.05

After adding the variable, the path coefficient for the direct effect was decreased to 0.258. Nevertheless, the direct effect is still showed positive relationship. Whereas, the path coefficient for likability of Korean dramas to attitude toward South Korea was recorded as 0.407, and the attitude toward South Korea to behavioural intentions toward South Korea was 0.433 (Table 8). The model was tested further by bootstrapping to calculate the significance.

The confidence interval (CI) of $95 \%$ was reported as shown in Table 8 . The p-value result for the direct and indirect effects showing $p<0.000$ indicated that the effects in the model were significant, thus $\mathrm{H} 3, \mathrm{H} 4$ and $\mathrm{H} 5$ were supported.

Since both of the direct and indirect effects showed significant and positive results, mediation occurred in the model. The attitude toward South Korea was considered a partial complimentary mediator in the relationship according to the mediator model (Zhao et al., 2010; Hair et al., 2017). Therefore, H7 is supported, where the attitude toward Korea act as partial mediator in the positive relationship between likability of Korean dramas and behavioural intentions toward Korea.

Table 9. Coefficient of determination $\left(R^{2}\right)$ and predictive relevance $\left(Q^{2}\right)$ for likability of Korean dramas model

\begin{tabular}{lcc}
\multicolumn{1}{c}{ Construct } & $\mathbf{R}^{2}$ & $\mathbf{Q}^{2}$ \\
Behavioural Intentions toward South Korea & 0.345 & 0.224 \\
Attitude toward South Korea & & 0.064 \\
\hline
\end{tabular}


Table 10. Effect size (f2) for likability of Korean dramas model

\begin{tabular}{lcc} 
& $\begin{array}{c}\text { Attitude towards South } \\
\text { Korea }\end{array}$ & $\begin{array}{c}\text { Behavioural Intentions } \\
\text { toward South Korea }\end{array}$ \\
$\begin{array}{l}\text { Behavioural Intentions toward } \\
\text { South Korea }\end{array}$ & 0.239 & \\
Likability of Korean Dramas & 0.198 & 0.085 \\
\hline
\end{tabular}

The $\mathrm{R}^{2}$ value reported suggested to be on the substantial level according to Cohen (1988) level of predictive accuracy. Likability of Korean dramas and attitude toward South Korea explained $34.5 \%\left(\mathrm{R}^{2}=0.345\right)$ of the variance of behavioral intentions toward South Korea. Results for predictive relevance $\left(\mathrm{Q}^{2}\right)$ and effect size $\left(\mathrm{f}^{2}\right)$ value were reported in Table 9 and Table 10 respectively.

\section{DISCUSSION}

Results showed that the hypotheses proposed in this study were supported. Korean dramas were able to influence the viewers' behavioural intentions toward South Korea. The findings proved that both the viewing of Korean dramas and the likability of Korean dramas were able to yield a positive attitude toward South Korea and thereby affect the viewers' behavioural intentions toward Korea positively. Even though, the statistical results showed low correlation between the independent variables and dependent variables proposed, the positive results shown should not be ignored as they had proven that Korean dramas have impact on their viewers.

\section{Viewing of Korean dramas}

The findings showed that Malaysian Youth who watched Korean dramas over a period of time, tend to have their behavioural intentions toward South Korea affected positively. According to the Cultivation theory (Gerbner \& Gross, 1976), Malaysian Korean drama viewers can be affected by the dramas after watching for a period of time. Malaysian viewers also showed positive attitude toward South Korea after watching Korean dramas. This finding was supported as dramas are said to be able to produce positive attitude on the country of origin (Köksal \& Gjana, 2015). Hence, the Korean dramas could influence Malaysian viewers by showing impact on their behaviours, where they have positive attitude and behavioural intentions toward Korea. It can be said that the Cultivation effect for Korean drama did occurred on Malaysian viewers. This finding was similar to previous research done on the effect of drama viewing on viewers' behaviours in different countries, such as Taiwan, Thailand and Japan (Hasegawa, 2006; Namdar et al., 2013; Köksal \& Gjana, 2015; Yoo et al., 2014; Chang, 2015; Ainslie, 2016).

\section{Likability of Korean dramas}

Likability of Korean dramas was also proven to have affected the Malaysian viewers' behavioural intentions towards South Korea. Their positive feelings and interest on the Korean dramas were able to yield positive attitude and positive behaviours toward South Korea. The level of liking for Korean drama was said to be able to influence the viewers' attitude toward South Korea and it was important for the viewers to have positive attitude 
toward South Korea (Lee et al., 2015; Wu \& Wang, 2017).

The liking of Korean dramas could be more important in influencing foreign viewers suggesting that foreign viewers need to accept and show affection for the Korean dramas in order to be influenced by the media. By showing positive liking toward the Korean dramas they have watched, meant that they have had positive evaluation and watching experience (Murry et al., 2012).

\section{Attitude toward Korea}

As the results shown by the statistical analysis, attitude toward South Korea had positive effect on the behavioural intentions toward South Korea and acted as a partial complimentary mediator in the model. This had suggested that the Cultivation effect and likability of Korean drama did not fully impact the viewer's behavioural intentions. These effects on the viewers' behaviours could be mediated by another variable. In this case, attitude toward South Korea mediated the direct effects on behavioural intentions toward South Korea as proposed in the model. Prolonged watching period and likings toward Korean dramas cannot assure strong positive behavioural intentions toward South Korea as this could be due to the viewers' attitude formed toward South Korea. Nevertheless, positive attitude or impression toward the country was expected if liking for the media occurs (Murry et al., 2012).

\section{CONCLUSION}

Overall, this study argues that Malaysian youths' attitude toward South Korea can affect their behavioural intentions towards South Korea and influenced by viewing and liking of Korean dramas. Malaysian youth who watch Korean dramas attentively have shown the same result as other countries' Korean drama viewers, where they have positive attitude and behaviours toward South Korea (Hasegawa, 2006; Kim et al., 2009; Su et al., 2011; Yoo et al., 2014; Chang, 2015; Lee et al., 2015; Wu \& Wang, 2017). Nevertheless, the impact of viewing and liking of Korean dramas on the Malaysian youths' viewers' behavioural intentions toward South Korea are weak. This study also found out that their behavioural intentions are partial mediated by their attitude towards South Korea.

Attitude or perception toward the country of origin can affects the media influence. South Korea uses media as a form of soft power (Chung, 2018). Hence, a country needs to maintain a good image in the public's eyes for them to practice soft power. The government of a country have to take note the importance to portray a good image of their country. Their country's image can be reflected using media, such as drama and film. Malaysia's government can learn from South Korea as how they use their entertainment industry to increase foreign' interest in their country and show a good country's image.

Although the behaviours mentioned in this study are behavioural intentions, it had also been proved that Malaysian youth did show likings toward South Korea and their products. Marketers or entrepreneurs could seize the opportunity of this Korean wave to sell Korean products in Malaysia as there are demands from the market. Malaysian youth who watch Korean dramas had shown positive behavioural intention toward South Korea, as their thinking and behaviours were influenced. Subconsciously, they might have incorporated some of the Korean culture learned from the Korean media into their lives as they became engrossed in the dramas. For example, they might incorporate some of the Korean words 
and expressions ('annyeong', 'oppa', etc) they learned from the dramas they watched into their daily discourse. This could cause the Malaysian Korean drama viewers to have their Malaysian culture instilled since they were young to be altered to some extent. However, since Malaysia and South Korea are both Asian countries, the way of thinking may not differ much besides the culture elements.

\section{ACKNOWLEDGEMENTS}

Authors would like to thank Professor Dr.V.K. Kumar (Department of Psychology, West Chester University of Pennsylvania) for the kind help to edit this manuscript.

\section{REFERENCES}

AirAsia. (2016, September 23). AirAsia sponsors KBS Korean drama 'On the way to the airport'. AirAsia. Retrieved from https://www.airasia.com/ph/en/press-releases/ airasia-sponsors-kbs-korean-drama-on-the-way-to-the-airport.page

Aisyah, F. (2019, July 29). Business riding on the Hallyu wave. The Malaysian Reserve. Retrieved from https://themalaysianreserve.com/2019/07/29/businesses-riding-on-thehallyu-wave/

Ainslie, M. J. (2016). K-dramas across Thailand: construction of Koreanness and Thainess by contemporary Thai consumers. The Asia-Pacific Journal, 14(7), 1-13.

Ariffin, J. T. (2016). Korean television drama in attracting Malaysian audiences: media strategy perspective. International Journal of Engineering Research and Management, 3(7), 38-42. doi: 10.21276/ijirem.2018.5.1.3.

Ariffin, J. T., Bakar, H. A. \& Yusof, N. H. (2018). Culture in Korean drama towards influencing Malaysian audiences. International Journal of Innovative Research in Engineering and Management, 5(1), 10-14.

Begum, M. (2019, July 18). From BTS to K-dramas, you can't escape the Korean wave. Star2. com. Retrieved from https://www.star2.com/entertainment/2019/07/18/koreanwave-stronger-than-ever/

Bibi, N. R. (2016, October 14). Korean superstar Park Shin-Hye brings the house down at 1Utama [Video]. New Straits Times. Retrieved from http://www.nst.com.my/ news/2016/10/180364/korean-superstar-park-shin-hye-brings-house-down1utama-video

Carveth, R., \& Alexander, A. (1985). Soap opera viewing motivations the cultivation process. Journal of Broadcasting and Electronic Media, 29(3), 259-273. doi: 10.1080/08838158509386584.

Chang, J. C. (2015). Korean wave as a factor on Taiwan's entertainment, consumer behavior, and cultural identity: a case study about "My love from the star". Journal of Human and Social Science Research, 6(2), 74-79.

Cho, C. H. (2010). Korean wave in Malaysia and changes of the Korea-Malaysia relations. Malaysian Journal of Media Studies, 12(1), 1-14.

Cho, Y. C., \& Agrusa, J. (2007). How the media is a significant promotional tool to deliver marketing messages to audiences?. International Business and Economic Research Journal, 6(10), 61-74. doi: 10.19030/iber.v6i10.3418. 
Chung, K. Y. (2018). Media as soft power: The role of the South Korean media in North Korea. Journal of Communication, 25(1), 137-157. doi: 10.1080/13216597.2018.1533878.

Cohen, J. (1988). Statistical power analysis for the behavioral sciences ( $2^{\text {nd }}$ ed.). Mahwah: Lawrence Erlbaum Associates. doi: 10.4324/9780203771587.

Creighton, M. (2009). Japanese surfing the Korean wave: Drama tourism, nationalism, and gender via ethnic eroticisms. Southeast Review of Asian Studies, 31, 10-38.

Enikolopov, R., \& Petrova, M. (2018). Mass media and its influence on behaviour. Centre de Recerca en Economia Internacional, 44, 1-46.

Fornell, C., \& Larcker, D. F. (1981). Evaluating structural equation models with unobservable variables and measurement error. Journal of Marketing Research, 18(1), 39-50. doi: $10.1177 / 002224378101800104$.

Gerbner, G. \& Gross, L. (1976). Living with television: The violence profile. Journal of Communication, 26(2), 172-194. doi: 10.1111/j.1460-2466.1976.tb01397.x.

Gerbner, G., Gross, L., Morgan, M., \& Signorielli, N. (1986). Living with television: The dynamics of the cultivation process. Perspective on Media Effects, 17-40.

Hair, J. F., Hult, G. T. M., Ringle, C. M., \& Sarstedt, M. (2017). A primer on partial least square structural equation modeling (PLS-SEM) ( $2{ }^{\text {nd }}$ ed.). Thousand Oaks: Sage Publications, Inc. doi: 10.2753/MTP1069-6679190202.

Han, C. M. (1990). Testing the role of country image in consumer choice behaviour. European Journal of Marketing, 24(6), 24-40. doi: 10.1108/EUM0000000000609.

Hasegawa, N. (2006). A quantitative analysis of Japanese image of Korea: Perceptual changes brought about by TV drama viewing. Intercultural Communication Studies, XV(1), 77-86.

Hassim, N., Jayasainan, S. Y., \& Khalid, N. L. (2019). Exploring viewer experiences with sageuk K-dramas from a parasocial relations perspective. SEARCH Journal of Media and Communication Research, 11(1), 77-94.

Henseler, J., Ringle, C. M., \& Sarstedt, M. (2015). A new criterion for assessing discriminant validity in variance-based structural equation modeling. Journal of the Academy of Marketing Science, 43(1), 115-135. doi: 10.1007/s11747-014-0403-8.

Huang, X. (2009). 'Korean wave": The popular culture, comes as both cultural and economic imperialism in the East Asia. Asian Social Science, 5(8), 123-130.

Jalaluddin, N. H., \& Ahmad, Z. (2011). Hallyu in Malaysia: a socio-cultural study. Malaysian Journal of Communication, 27(2), 203-219.

Kim, D. K., Arvind, S., Hanaki, T., Dunn, J., Chitnis, K., \& Han, M. W. (2009). Television drama, narrative engagement and audiences buying behavior: the effects of Winter Sonata in Japan. International Communication Gazette, 71(7), 595-611. doi: 10.1177/1748048509341894.

Köksal, Y., \& Gjana, N. I. (2015). Soap opera effect on product preferences in terms of country image: a case of Turkish TV serials in Albanian market. Journal of Economic and Social Studies, 5(1), 219-238. doi: 10.14706/JECOSS11513.

Kumar, P. P., \& Zainuddin, A. (2019, January 2). Govt mulls amending law to redefine age of youths. The Malaysian Reserve. Retrieved from Retrieved from https://themalaysianreserve. com/2019/01/02/govt-mulls-amending-law-to-redefine-age-of-youths/

Lam, T., \& Hsu, C. H. C. (2006). Predicting behavioral intention of choosing a travel destination. Tourism Management, 27, 589-599. doi: 10.1016/j.tourman.2005.02.003. 
Lee, B., Ham, S., \& Kim, D. (2015). The effect of likability of Korean celebrities, dramas, and music on preferences for Korean restaurants: a mediating effect of a country image of Korea. International Journal of Hospitality Management, 46, 200-121. doi: 10.1016/j. ijhm.2014.05.012.

Lemish, D. (1985). Soap opera viewing in college: a naturalistic inquiry. Journal of Broadcasting and Electronic Media, 29(3), 275-293. doi: 10.1080/08838158509386585.

Lita, R., \& Cho, Y. C. (2012). The influence of media on attitudinal and behavioral changes: acceptance of culture and products. International Business and Economics Research Journal, 11(12), 1433-1444. doi: 10.19030/iber.v11i12.7617.

Murry, J. P. Jr., Lastovicka, J. L., \& Singh, S. N. (1992). Feeling and liking responses to television programs: An examination of two explanations for media-context effects. Journal of Consumer Research, 18, 441-451. doi: 10.1086/209272.

Namdar, H., Hassaan, M., \& Naseem, M. A. (2013). Effect of local television dramas on consumer behavior of females. European Journal of Business and Management, 5(3), 161-166.

O'Connor, N., Flanagan, S., \& Gilbert, D. (2008). The integration of film-induced tourism and destination branding in Yorkshire, UK. International Journal of Tourism Research, 10(5), 423-437. doi: 10.1002/jtr.676.

Russell, C. A., Stern, B. B., \& Stern, B. B. (2006). Consumers, characters, and products: a balance model of sitcom product placement effects. Journal of Advertising, 35(1), 7-21. doi: 10.2753/JOA0091-3367350101.

Severin, W. J. \& Tankard, J, W. Jr. (2014). Communication theories origins, methods and uses in mass media ( $5^{\text {th }}$ ed.). London: Pearson Education Limited.

Solimun, \& Fernandes, A. A. R. (2017). Investigation the mediating variable: What is necessary? (Case study in management research). International Journal of Law and Management, 59(6), 1059-1067. doi: 10.1108/IJLMA-09-2016-0077.

Son, S., \& Kijboonchoo, T. (2016). The impact of Korean wave on the purchase intention of Korean cosmetics of Thai people in Bangkok and Chonburi, Thailand. PSAKU International Journal of Interdisciplinary Research, 5(2), 76-83.

Su, H. J., Huang, Y. A., Brodowsky, G., \& Kim, H. J. (2011). The impact of product placement on TV-induced tourism: Korean TV dramas and Taiwanese viewers. Tourism Management, 32, 805-814. doi: 10.1016/j.tourman.2010.06.020.

Suh, Y. G., Hur, J. Y., \& Davies, G. (2016). Cultural appropriation and the country of origin effect. Journal of Business Research, 69(8), 2721-2730. doi: 10.1016/j.jbusres.2015.11.007.

Touhami, B., \& Al-Haq, F. A. (2017). The influence of the Korean wave on the language of international fans: case study of Algerian fans. Sino-US English Teaching, 14(10), 598-626. doi: 10.17265/1539-8072/2017.10.004.

Tsai, H. M. T., \& Lu, Y. T. (2012). The effect of connectedness of television consumption on country of origin image and brand attitude: an empirical study of Korean TV series. Marketing Review, 9(4), 417-442. doi: 10.29931/MR.201212.0003.

West, R., \& Turner, L. H. (2014). Introducing communication theory (5 $5^{\text {th }}$ ed.). New York: McGraw Hill Education.

Wong, K. K. K. (2013). Partial least square structural equation modeling (PLS-SEM) techniques using SmartPLS. Marketing Bulletin, 24(1), 1-32. 
Wu, S. H., \& Wang, T. Y. (2017). The relationships of likability of Korean drama toward the premium of Korean product and travel intention. Taiwan Journal of International Business Studies, 11(1), 59-84. doi: 10.3966/199553922017031101003.

Yoo, J. W., Jo, S., \& Jung, J. (2014). The effects of television viewing, cultural proximity, and ethnocentrism on country image. Social Behavior \& Personality: An International Journal, 42(1), 89-96.

Yunus, A., \& Landau, E. (2019, July 3). 'Youth' now defined as those between 15 and 30. New Straits Times. Retrieved from https://www.nst.com.my/news/nation/2019/07/501288/ youth-now-defined-those-between-15-and-30

Zailin, Z. A., Khalifah, O., \& Ridhuan, T. A. (2014). Analyzing the dimension of Korean popular culture among Malaysian adolescent. In $5^{\text {th }}$ International Conference on Humanities and Social Sciences (pp. 11-35). Prince of Songkla University, Thailand.

Zhao, X., Lynch, J. G., \& Chen, Q. (2010). Reconsidering Baron and Kenny: myths and truth about mediation analysis. Journal of Consumer Research, 37(2), 197-206. doi: 10.1086/651257. 